
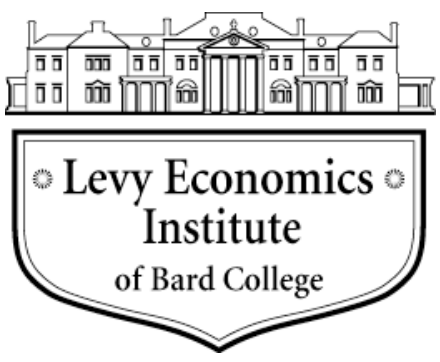

Working Paper No. 745

\title{
Stock-flow Consistent Modeling through the Ages
}

by

\author{
Eugenio Caverzasi \\ University of Pavia
}

Antoine Godin*

University of Pavia

\section{January 2013}

* Corresponding author: godin.antoine@gmail.com.

The Levy Economics Institute Working Paper Collection presents research in progress by Levy Institute scholars and conference participants. The purpose of the series is to disseminate ideas to and elicit comments from academics and professionals.

Levy Economics Institute of Bard College, founded in 1986, is a nonprofit, nonpartisan, independently funded research organization devoted to public service. Through scholarship and economic research it generates viable, effective public policy responses to important economic problems that profoundly affect the quality of life in the United States and abroad.

\author{
Levy Economics Institute \\ P.O. Box 5000 \\ Annandale-on-Hudson, NY 12504-5000 \\ http://www.levyinstitute.org
}

Copyright (C) Levy Economics Institute 2013 All rights reserved

ISSN 1547-366X 


\begin{abstract}
The aim of the paper is to provide an overview of the current stock-flow consistent (SFC) literature. Indeed, we feel the SFC approach has recently led to a blossoming literature, requiring a new summary after the work of Dos Santos (2006) and, above all, after the publication of the main reference work on the methodology, Godley and Lavoie's Monetary Economics: An Integrated Approach to Credit, Money, Income, Production and Wealth (2007). The paper is developed along the following lines. First, a brief historical analysis investigates the roots of this class of models that can be traced as far back as 1949 and the work of Copeland. Second, the competing points of view regarding some of its main controversial aspects are underlined and used to classify the different methodological approaches followed in using these models. Namely, we discuss (1) how the models are solved, (2) the treatment of time and its implication, and (3) the need — or not—of microfoundations. These results are then used in the third section of the paper to develop a bifocal perspective, which allows us to divide the literature reviewed according to both its subject and the methodology. We explore various topics such as financialization, exchange rate modeling, policy implication, the need for a common framework within the post-Keynesian literature, and the empirical use of SFC models. Finally, the conclusions present some hypotheses (and wishes) over the possible lines of development of the stock-flow consistent models.
\end{abstract}

Keywords: Stock-flow Consistent; Post-Keynesian; Literature Review JEL Classifications: B59, C69, E12 


\section{STOCK-FLOW CONSISTENT MODELS}

Recent Post-Keynesian literature has witnessed the rise of a relatively ${ }^{1}$ new family of models: the so-called stock-flow consistent (SFC) models. This paper analyzes the most important contributions in this area of research, with a particular focus on the latest works. What we aim to obtain is a clear picture of the current state of the art of SFC models as well as an improved understanding of their possible lines of development.

The outline of the paper is as follows. In this introductory section, we first present some of the most generic findings of our investigation. We then trace the steps that led to this class of model in a brief historical survey. The second section presents some of the methodological and theoretical debates about these models: the solution of the model, the role of time, and the micro-foundations. Sections 3-5 include a review of the most recent papers discussing SFC models, divided according to their methodology and subjects: (1) theoretical models with a discursive solution, (2) theoretical models solved via simulation, and (3) empirical models. The second group has been further partitioned according to the subjects treated. In this case, we individuated four macro areas: financialization, open economies, policy implications, and theoretical debate. Finally, the conclusion uses the evidence emerging from the analysis of the previous sections to develop some hypotheses (and wishes) of the possible lines of development of SFC models.

\subsection{Graphical Overview}

Before entering the core of our paper and analyzing the characteristics of the SFC framework, we would like to provide a rapid overview of some of the results of our investigation with the help of three graphs. Figure 1 shows the network of all authors cited in this paper. ${ }^{2}$ Each author is a node and connections represent paper collaborations. We have highlighted in black all authors with five or more cited publications. What emerges from this figure are two subnetworks: the first centered around the contributions of Wynne Godley, Marc Lavoie, Gennaro Zezza, and Claudio Dos Santos, which we could characterize as the North American group, ${ }^{3}$ and

\footnotetext{
${ }^{1}$ As we will show, the roots of these models date rather far back in time. However, only in the last ten years have they seemed to attract a wider consensus, at least in the heterodox academic community.

${ }^{2}$ All graphs presented in this section are automatically generated using the bibliography as a database; the $\mathrm{R}$ source code is available from the authors upon request.

${ }^{3}$ Gennaro Zezza is located in Italy, but is a Levy Institute scholar, while Claudio Dos Santos is in Brazil now, but holds a Ph.D. from the New School for Social Research.
} 
the second emerging from the works of Jacques Mazier, Stephen Kinsella, and Edwin Le Heron, which we could call the European group. It is important to bear in mind that this graph only provides for a partial representation of the links among authors. Indeed, the connections between points only represent co-authorships; other kinds of relations are not captured. Furthermore, the proximity in our network does not indicate actual vicinity, either geographical or otherwise. These deficiencies emerge as self-evident when looking, for example, at the European group that appears to be split. There seems to be an isolated "galaxy" centered on Le Heron, while French scholars have, in fact, created a network of collaborations that goes beyond co-authorships.

Figure 1 Network of authors working in the SFC framework

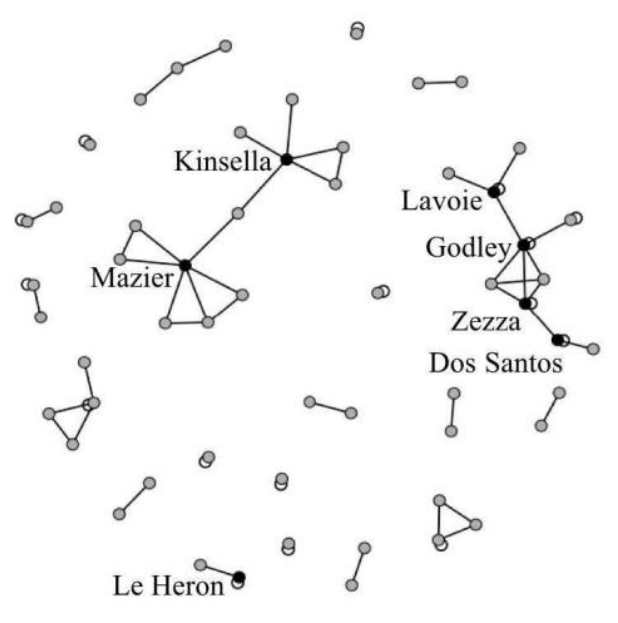

The second analysis we conducted, based on the bibliography we have gathered, regards the appearance of different assets and sectors. Indeed, while the first models were relatively simple, the development of the literature has witnessed an increase in the number of assets modeled. The same is true for sectors. Figures 2 and 3 show the timeline of the appearance of each asset and sector. It also indicates the frequency of modeling: the darker the cell, the more frequently the asset/sector was modeled in that year. For example, in 2010, equities were more frequent than bills in the same year, or than equities a year before. These timelines allows us to see not only the diversity of assets (Figure 2) modeled, but also the trends. In 2008, just after the burst of the housing bubble in the US, we observe that the housing market is modeled. We observe that, at first, assets were not diversified that much, but that the current crises compelled authors to develop more and more complex models of the financial market. 
Figure 2 Assets' appearance through time in SFC models

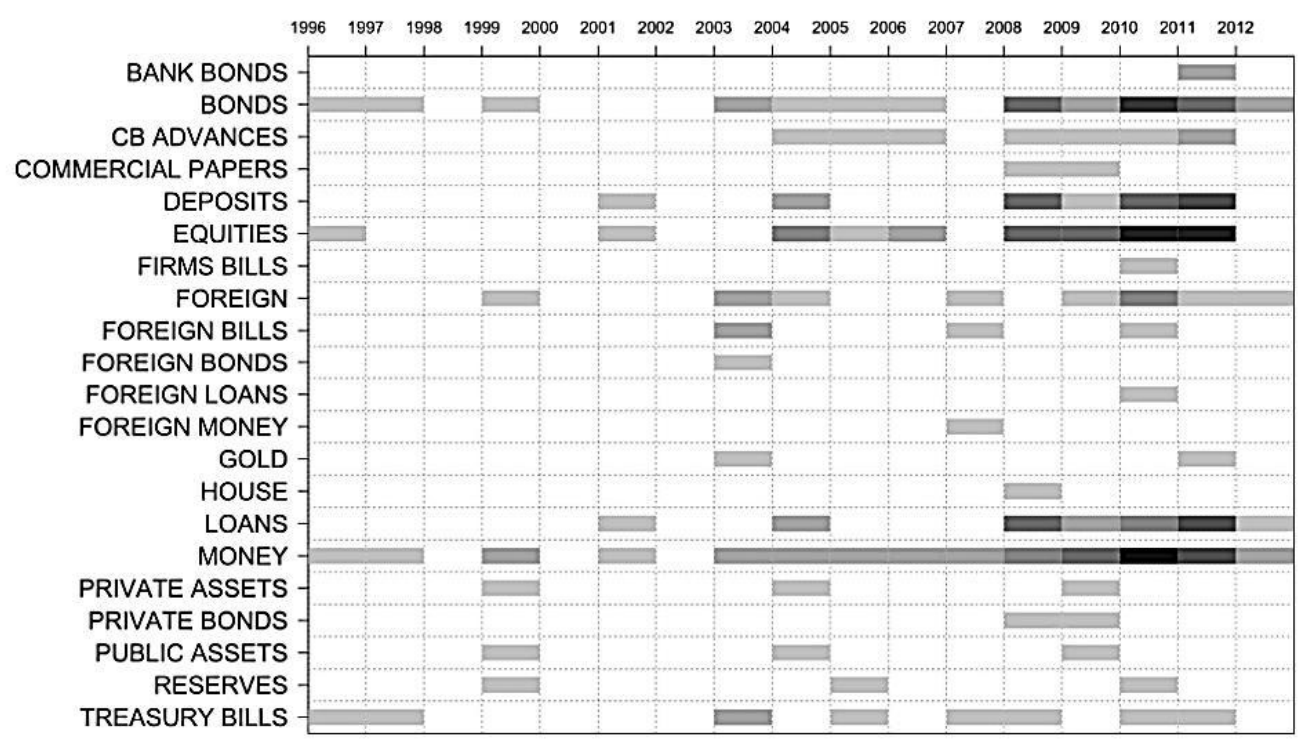

Note: The darker the cell, the more frequently the asset was modeled.

The evolution of sectors (Figure 3) presents a lower level of diversification than that of assets. This can be easily explained. An increase in the number of assets or sectors determines a significant amount of growth of the complexity of the models. It thus seems that the authors concentrated on modeling a more realistic financial market, rather than a more realistic productive structure or household structure. Nonetheless, the appearance of the differentiation between households and capitalists indicates that distributive issues have been addressed.

Figure 3 Sectors' appearance through time in SFC models

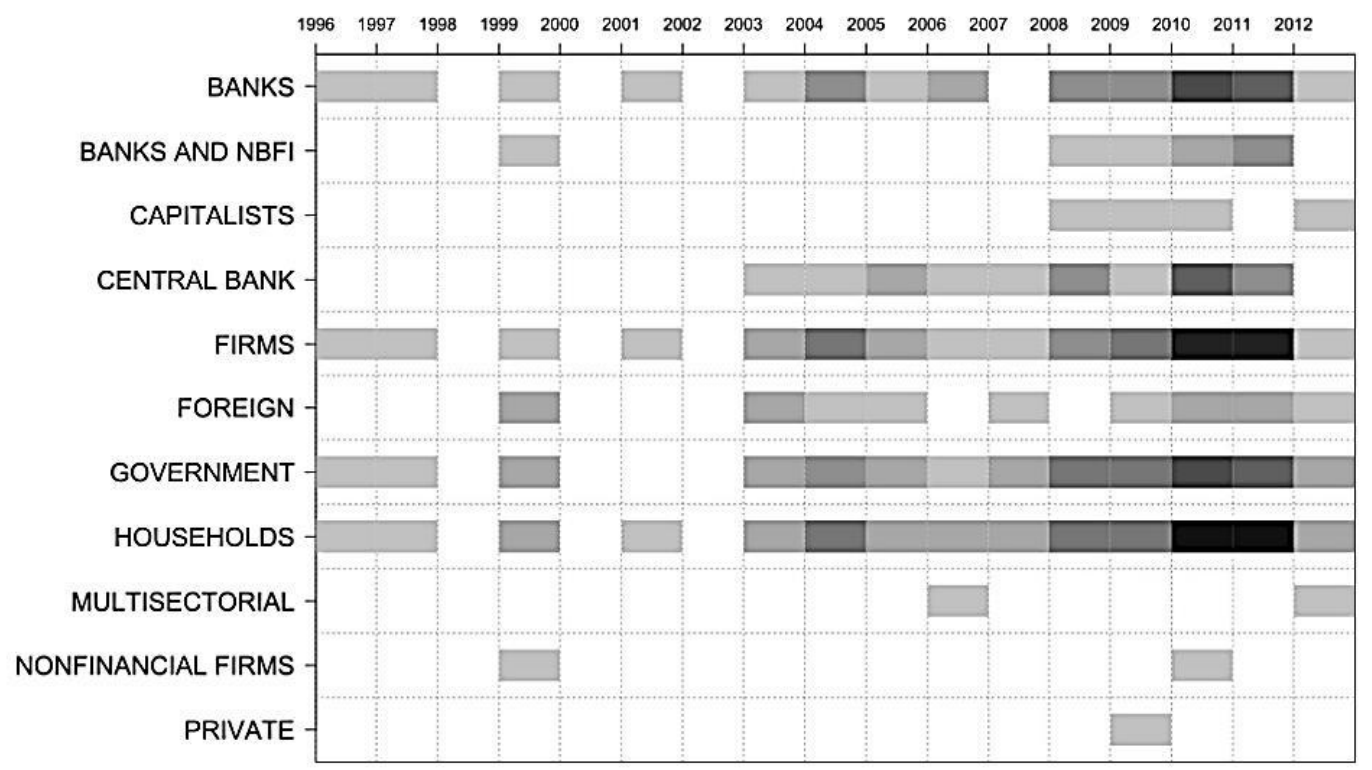

Note: The darker the cell, the more frequently the sector was modeled. 


\subsection{A Brief Historical Recollection}

The main characteristics of SFC models will be extensively (we hope) addressed in this paper, but for the moment we will try to describe their very basic characteristics, rapidly answering these two questions: what are SFC models, and where do they come from? With respect to the first question, we can say that SFC models are specific kinds of macro models that try to coherently integrate all stocks and flows of an economy. Broadly speaking, we can identify two main components: (1) the accounting framework, and (2) the behavioral equations. ${ }^{4}$ The first of these two components usually relies on a set of matrices reproducing the balance sheets, the transactions, and the capital gains of each of the institutional sectors into which the economy is subdivided. The second component is a set of behavioral equations modeling all the transactions not directly determined by the accounting structure of the economy.

Where do SFC models come from? Their roots are to be identified in the work of Morris A. Copeland (1949), who, with his study on "money flows," is the father of the flow of funds (for the US, "Federal Reserve Bureau Z.1 Release"). The intuition of Copeland was to enlarge the social accounting perspective - which had been until then used mainly in the study of national income - to the study of money flows. Hence, with his attempts to find answers to fundamental economic questions such as "when total purchases of our national product increase, where does the money come from to finance them" and "when purchases of our national product decline, what becomes of the money that is not spent," he laid the foundation for an economic approach able to integrate real and financial flows of the economy (Copeland 1949, p. 254). A concrete example of his legacy is represented by the quadruple-entry system, which is a cardinal feature of today's SFC models: that since someone's inflow is someone else's outflow, the standard double-entry system of accounting, in its social version, is doubled in a quadrupleentry system.

As observed after twenty-five years by Cohen (1972), the work of Copeland certainly had a great influence on economics - mainly as a source of financial data — but its potential disruptive impact on the study and modeling of the interdependences between real and financial flows failed to occur (at least until the time in which Cohen was writing). As to the possible causes of this missed evolution of economics, Cohen indicates "the lack of a so-called

\footnotetext{
${ }^{4}$ Appendix A contains the transaction flow matrix (Appendix - Table 1) and balance sheet (Appendix - Table 2) for model SIM (see Godley and Lavoie 2007c, chapter 3). The appendix also contains the model's behavioral equations.
} 
'organizing theory,"” or in other words, "they lack their Keynes" (Jacob 1972, p. 13). Albeit in the 1970s, several authors within the orthodox tradition tried to formulate models able to include coherently real and financial stocks and flows, but all failed to comprehend the potential theoretical contribution of the work of Copeland, and their efforts did not result in a well-suited alternative macroeconomic framework. Among others, Denizet (1967) based his analysis on a framework very similar to the SFC methodological approach, proposing "a transactions flow matrix that has implicitly all the features of the matrices that were later produced explicitly by Tobin [...] and systematically by Godley" (Lavoie 2011, p. 4). Turnovsky (1977) tried to include financial markets in the standard IS/LM (Investment-Saving/Liquidity preference-Money supply) framework, expanding the work of previous authors, such as May (1970) on continuous and discrete time in the analysis of stocks and flows, and Meyer (1975) on the coherence between stocks and flows ("conservation principle"). It was only in the 1980s with the work of James Tobin that these efforts culminated in the organizing theory advocated by Cohen. The article he wrote with David Backus, William C. Brainard, and Gary Smith (Backus et al. 1980) perhaps represents his path-breaking contribution in the foundation of SFC models. Indeed, in developing an empirical model of the US economy in both its financial and non-financial sides, the authors combined the theoretical hypothesis on the behavior of the economy with a rigorous accounting framework based on the flow-of-funds social account developed by Copeland. The result is a stock-flow consistent model that includes some of the characteristics still peculiar in the literature, such as the matrices-based accounting approach and discrete time ${ }^{5}$ and other features, such as the stock-flow identity, which are fundamental in any model of this type. The importance of Tobin's contribution is probably more evident if we take into consideration his Nobel lecture (Tobin 1982), which in specific passages resembles a manifesto of this approach, since it neatly defines and illustrates its components. Tobin identifies five defining features underlying the innovative character of his work, with respect to existing macro model:

1. Precision regarding time.

2. Tracking of stocks.

3. Several assets and rates of return.

4. Modeling of financial and monetary policy operations.

5. Walras's Law and adding up constraints.

\footnotetext{
${ }^{5}$ This was a practical reason, reflecting the quarterly availability of data in the flow-of funds.
} 
These are not only still central in any ${ }^{6}$ SFC model — as highlighted by Godley and Lavoie (2007c, p. 15), according to which, differences with Tobin were not in the methodology but in the specification of the behavioral equation - but have been used as a definition of the SFC approach (Dos Santos 2006). The heritage of the work of Tobin was lost in the New Keynesian tradition he belonged to because of the rise of the representative agent-based macro models.

Next to Tobin and to the Yale school he led, the other scholar who played an essential role in the development of this family of models is Wynne Godley. Godley, head of the New Cambridge school (or Cambridge Economic Policy Group-CEPG) in the 1980s, started developing models coherently integrating stocks and flows (Godley and Cripps 1983; Godley and Zezza 1989). His efforts culminated in the organized framework he developed in his more recent publications (Godley 1996, 1997, 1999a), with which—albeit belonging to a different theoretical tradition - he collected the legacy of Tobin. Godley's contribution probably finds its peak in the book he wrote together with Marc Lavoie (Godley and Lavoie 2007c), which is still the main reference for current SFC practitioners. Whether Tobin or Godley is to be considered the father ${ }^{7}$ of SFC models (or the "Keynes of the flow-of-funds," in the words of Cohen) is controversial. We believe it depends on whether the label "stock-flow consistent" is applied specifically to the models in the Post-Keynesian tradition $^{8}$ (therefore, clearly the father would be Godley) or to any model with the characteristics we recall above (in this case, the father would be Tobin).

This paper-although not taking a side in this debate-focuses on the tradition descending from the work of Wynne Godley. This, indeed, represents the main aspect of the novelty of our work, since we believe a comprehensive review of older SFC models can be found in Godley and Lavoie (2007c), whereas an insightful analysis of the link between these models and Keynesian macroeconomic literature has been developed by Dos Santos (2006).

\section{THEORETICAL CONSIDERATIONS}

In this section, we introduce three debates on methodological and theoretical issues regarding SFC modeling. First, we account for the part of the literature related to these topics. Second, we

\footnotetext{
${ }^{6}$ Both in the orthodox and in the heterodox schools of thought.

${ }^{7}$ On this matter, it is interesting to notice SFC models are defined "à la Godley" by Zezza (2004), "à la Godley and Tobin" by Dos Santos and Zezza (2004), and more recently "à la Godley and Tobin" by Clévenot, Guy, and Mazier (2009).

${ }^{8}$ Zezza (2011) is aware of this issue and refers to a more specific definition: SFC-PK.
} 
believe that a brief overview of these debates can facilitate the understanding of both the peculiarities of this class of models and their level of development.

\subsection{Solving the Model: Analytic vs. Simulated}

There exist two main ways of solving an economic model: numerically and analytically. This paper identifies a third possible way-a discursive solution. However, since this does not represent a proper solution of the model, it will be treated briefly at the end of the section.

The steps leading up to a numerical solution are the following: First, numerical values for the parameters are individuated, generally basing the choices on the observation of stylized facts. Second, the model is calibrated or estimated ${ }^{9}$ - that is, values for the different parameters and exogenous variables are determined. Once this is done, a steady state is usually computed. The third and last step consists of simulations. In practice, these are changes in the value of the parameters or of the exogenous variables, which allows us to see how the economy reacts. This methodology is, by far, the most widely used among SFC practitioners. The main reason behind this is that it permits the inclusion of virtually any specification and, therefore, the construction of more realistic models without losing the possibility of identifying the causal relations among variables. However, the numerical approach to the solution of the model, in addition to its manifest advantages, presents some drawbacks. As Lavoie and Godley (2002, p. 296) note, "the disadvantage is that we can only analyze local stability: we do not know if there are other equilibria, or if these other equilibria are stable.” Dos Santos and Macedo e Silva (2009, p. 9) identify two further problems related to this methodology, which in their view might have been unfavorable to the diffusion of SFC models. First, their mathematical complexity, which, especially in very large models, can make the economic intuition nebulous; and second, the dependency on the value of the parameters, as recognized as well by Lavoie and Godley (2002, p. 296): "the results could be, and in many cases certainly are, sensitive to the values taken by the assumed parameters." Even assuming that the starting values of parameters are founded on a perfectly solid empiric ground, this inevitably adds a certain degree of arbitrariness due to the calibration step. Taylor (2008) points out the importance of these stock-flow norms and shows how sometimes non-realistic values have to be assumed for the sake of having a realistic steady state.

\footnotetext{
${ }^{9}$ See Section 5 for more on the calibration/estimation step.
} 
The alternative is to find an analytical solution. Certainly, this forces us to develop a much simpler model, causing a loss of realism and not allowing for a complete representation of the most complex theories. However, it can still provide for interesting economic insights. In particular, as observed by Dos Santos and Macedo e Silva (2009) in their analysis of Dos Santos and Zezza (2008), in equilibrium, all flows and stocks grow at the same rate and, as a consequence, the ratios among variables are fixed. It is therefore possible to analyze the equilibrium according to the determinants of these ratios. In particular, they produce a graphical representation of the equilibrium conditions based on the considerations that the growth rates of the stocks of debt, capital, and households' wealth (rentiers in the original paper, since households are assumed to consume all their wage income) must equate. According to the author, this not only provides for a more intuitive approach to SFC models, but also represents a sensible development in the heterodox literature.

No one has ever stated clearly that the key to Post-Keynesian/structuralist/ heterodox dynamic analyses might be to take a close look at the dynamics of both the size and composition of the sectoral balance sheets ... This simple point is perhaps lost amidst the complex SFC algebra and dynamic simulations, but this does not make it any less true. (Dos Santos and Macedo e Silva, 2009, p. 31)

A third possibility is to use the accounting part of SFC models, and eventually the behavioral hypothesis, as a reference for a theoretical discursive paper. This approach will be more extensively investigated in Section 3.

\subsection{Time Matters}

As emphasized by Dos Santos and Zezza (2008, p. 444), SFC models provide "a natural and rigorous link between 'adjacent short periods." In each period, stocks are generating flows, which then update these stocks. These stocks will then generate new flows, and so on. The longrun dynamics of SFC models are thus composed of a path of short-run periods interconnected with each other via the stocks. This definition of long-run dynamics is close to what Keynes, Robinson, or Kalecki ${ }^{10}$ defined as long-run, as noted by Macedo e Silva and Dos Santos (2011). Furthermore, all of these short-run realizations depend on the steady-state values ${ }^{11}$ of the stocks,

\footnotetext{
${ }^{10}$ See Keynes (1936, chapter 5), Robinson (1956, pp. 180-81), and Kalecki (1971, p. 165).

${ }^{11}$ We differentiate between long-run and steady state. The steady state is a logical construction where all stocks and flows do not change over time. The steady state could be reached if all the behaviors where fixed forever, after a transition period. However, in the real world, behaviors are constantly changing, preventing the economy from ever reaching any steady state.
} 
whether they be stable or not. A much higher stable or exploding steady-state value of wealth is likely to imply a short-run realization of flows, implying increasing stocks of wealth. The further the current value of stock from its steady-state value, the more probable it is that the short-run period will show flows implying a large variation of stocks in the direction of their steady-state values. This will undoubtedly impact the long-run values of the stocks and flows. SFC models are thus inherently at the heart of the short-run/long-run debate. However, only a few authors using SFC models have focused on the debate (Dos Santos and Zezza 2008; Dos Santos and Macedo e Silva 2009; Skott and Ryoo 2007). Interestingly, all of these papers have concentrated their analysis on the analytical solution of their models, rather than on the simulated resolution. We find this to be very refreshing.

The rationality of the steady state has to be questioned. In order to obtain a steady state, some or all parameters have to be assumed constant and stock flow ratios have to be constant. A couple of questions then arise:

1. Is it relevant to analyze such a steady state, and is an economy likely to attain such a steady state? We believe, as do Dos Santos and Zezza (2008) and Dos Santos and Macedo e Silva (2009), that even if it is very unlikely that an economy reaches a situation where stocks and flows are constant over time, analyzing it is relevant because the steady state affects the dynamics of short-run realizations. Furthermore, it is easier to compare different policies using stationary states. Indeed, during out-of steady state, the stocks and flows are varying from period to period, and it is complicated to distinguish what comes out of the dynamics of the model as it settles and what emerges from the policy change.

2. What parameters should be assumed constant and how are the varying parameters related to the constant ones? The choice of the constant parameters and the determining stock flow norm is essential in defining a steady state and, in general, it characterizes the whole model. Each assumption will impact both the steady-state stock levels and the influence a shock might have on these values. This is clearly shown by Skott and Ryoo (2007), who define different economies leading to different steady-state long-run equilibriums and observe how financialization impacts each one of these steady states. They distinguish Harrodian from Kaleckian specification, mature from dual economies, and elastic from inelastic household behaviors. As Dos Santos and Macedo e Silva 
(2009), Skott and Ryoo define the Harrodian specification as the case where firms' capacity utilization is constant at its desired value. The Kaleckian specification, on the other hand, is a state of affairs where the profit share is constant-utilization rate being the endogenous value. Skott and Ryoo then differentiate what they call mature or laborconstrained versus dual economies, where the employment rate does not serve as a relevant system. Finally, they distinguish inelastic household behaviors where propensities - such as the propensity to save - are independent from return rates, from elastic ones, where these propensities vary through time.

Ryoo (2010) is an interesting example of medium- to long-run analysis without focusing on the steady state. He presents a continuous time SFC model based on short-run (variation in demand implying capacity utilization movements) and long-run (leverage and equity to deposit ratio movements) interactions. These two movements generate short cycles and long waves in an attempt to integrate two types of instability principles: Minsky's Financial Instability Hypothesis and Harrod's Instability Principle.

Lavoie and Zhao (2010) and Lavoie and Daigle (2011) are of great interest to this discussion since they highlight the path dependency of their model. Their papers will be discussed in Section 4.2. However, here, we want to stress this interesting outcome. Both of these models show how the same set of values of the parameters in the behavioral equations lead to different steady states, depending on the velocity at which the economy responds to the shock that hits it. This clearly shows again that the long-run - that is, the transition period from the initial situation when the shock is applied to the economy to the new steady state - is composed of short-run periods, but also that these short-run periods impact the long-run dynamics and thus lead to different steady-state situations. We believe that this path dependency, characteristic of SFC models, is essential for any macroeconomic model. Models that are not path dependent are unable to explain the different outcomes of the same policies applied in similar environment. Time matters.

\subsection{Micro-Foundations}

Recently, a new way to use the SFC framework has emerged. It consists of the combination of SFC and agent-based modeling ${ }^{12}(\mathrm{ABM})$. A common limit of ABM, in general, is that they do

\footnotetext{
${ }^{12}$ For more information regarding ABM, see Epstein and Axtell (1996), Tesfatsion and Judd (2006), and Borrill and Tesfatsion (2010).
} 
not usually have consistency between stocks and flows. Furthermore, as Bezemer (2011) points out, adding agent interactions instead of a representative agent in mainstream models (such as dynamic stochastic general equilibrium-DSGE) does not solve the incapacity of these models to forecast financial crises such as the 2007-08 crisis. This is why Bezemer calls for the combination of ABM with SFC models that specifically account for the financial sector. We believe, as do Bezemer and others, that the combination of the flexibility of agent-based modeling with the consistency between stocks and flows of the system provides a framework that ensures the compatibility of real and financial variables.

Seppecher (2012a) adds that ABM within the SFC framework allow for the solution of some paradoxes and difficulties arising from the use of aggregated models. He argues that the ABM methodology would bring three important characteristics: (1) the possibility of different lengths of the production process among agents; (2) the possibility of asynchronous decisions in consumption, investment, and other behaviors; and (3) the possibility to account for gross intrasectorial flows and stocks, rather than net sectorial ones.

The possibility of different production process lengths, indeed, allows us to solve the paradox of profit, ${ }^{13}$ as shown by Seppecher. ${ }^{14}$ Furthermore, the discrepancy in the length of processes leads inevitably to asynchronous behaviors, which brings the possibility of temporal disequilibrium and thus rejects the notion of optimizing behaviors. Indeed, because some decisions have to be made before the results of other decisions are known, agents have to use rules of thumb and cannot optimize their behaviors. Finally, we believe that the possibility to account for gross intra-sectorial flows and stocks may allow us to solve some fallacy of composition, such as the critique of Lavoie and Seccareccia (2001) on Minsky's Financial Instability Hypothesis. Indeed, it could well be the case that a sector as a whole does not show any sign of instability, while agents within the sector encounter financial difficulties, which could lead to sectorial instability.

To our knowledge, only two papers have been explicitly using an SFC-ABM methodology: Seppecher (2012b) and Kinsella, Greiff, and Nell (2011). However, the way in which the methodology has been used differs radically. Pascal Seppecher has developed JAMEL, a java agent-based macro economic laboratory, which allows him to simulate the

\footnotetext{
${ }^{13}$ See Messori and Zazzaro (2004) for more on the paradox of profits.

${ }^{14}$ Seppecher cites Zezza (2012) as another author having worked on the necessity of having different production times in order to solve the paradox of profits, even if Zezza demonstrates his results within an aggregated SFC model.
} 
interactions of households, firms, and banks. Seppecher (2012b) presents his first results and analyzes the impacts of wage rigidity and minimum wages on the economy. All behaviors are fairly simple and are based on rules of thumb rather than optimization, following Keynes. It is interesting to note that, although it doesn't demonstrate any explicit behavior aiming at a macroeconomic equilibrium, the model reaches it. The stringency of the macroeconomic SFC framework allows the author to observe interdependencies among otherwise independent microeconomic entities.

Kinsella, Greiff, and Nell (2011) follow a more traditional trend in the ABM literature. The model simulates many complex behaviors, such as investment in innovation both for firms (via innovative capital) and households (via education) or labor market dynamics. They model households, firms, banks, and a government, and analyze the rise of inequality among households. They show how, starting from a materialist equality, inequality emerges through competition.

We believe, as do Bezemer (2011) and Seppecher (2012a), that SFC-ABM is one way to challenge DSGE models. They offer a better micro-foundation to macroeconomic models and allow us to respond to critiques such as the fallacy of composition. ${ }^{15}$ Furthermore, they allow us to see how, as a simple rule of thumb, micro behavior generate complex macro trends. The drawback of these models is their tractability. Indeed, because of the multiplicity of interactions between agents and the resulting feedback, it is difficult — if not impossible — to grasp all the dynamics. To our understanding, ABM-SFC models should remain fairly simple and concentrate on a few selected behaviors, rather than try to fit the real world if they want to be of any explicative use.

\section{THEORETICAL MODELS, DISCURSIVE RESOLUTION}

The SFC approach is usually developed along three steps: “(1) do the (SFC) accounting; (2) establish the relevant behavioral relationships; and (3) perform 'comparative dynamics' exercises (generally with the help of computer simulations)" (Dos Santos 2005). The third of these steps - the so called solution of the model — allows for the understanding of how the

\footnotetext{
${ }^{15}$ It is worth noting that a compromise between aggregated macro models and agent-based models can be found in the so-called structuralist literature (Taylor 1983, 2004b). Structuralist models base their analysis on a disaggregated Social Accounting Matrix, allowing us to better observe structural and pricing interdependencies between sectors. The difficulty of such models resides in their complexity and in their ever-growing number of equations.
} 
economy behaves in time, if it tends toward equilibrium or if it presents an explosive behavior (more on this below). However, as we stated above, a model can be considered completed even before it has fulfilled this last step. As we said, SFC modeling is based on a comprehensive accounting framework, which, in the methodology developed by Godley, is based on a set a three matrices: (1) a stock matrix, representing the initial stocks of the economy; (2) a flow matrix, showing all the flows implied by initial stocks and by the decisions of the agents; and (3) a stocks revaluation matrix, making explicit how the flows of the period determine different stocks at the end of it. The consistency of the accounting is ensured by precise rules.

Next to the quadruple-entry system (see Section 1), the most important accounting rule is with respect to budget constraints, both of individual sectors and of the economy as a whole. This is defined alternatively as "Walras' law and adding up constraint" (Tobin 1982) and "budget constraint or system-wide consistency requirement" (Godley and Lavoie 2007c, p.14) and guarantees ${ }^{16}$ that "there are no black holes" (Godley 1996). Indeed, the three matrices, per se, represent a powerful tool in economic modeling since they provide for the solid foundations over which a model is erected, ensuring that nothing can be built in the air. It is not surprising, therefore, that a strand of the SFC literature is based exclusively on the accounting part of this approach. This section of our paper presents some of the main contributions of this kind, which we defined as models with a discursive solution. A good example ${ }^{17}$ is represented by Dos Santos (2006). The author develops an insightful comparison of the views of four "old financial Keynesian" scholars (definition drawn from the author): Paul Davidson, Wynne Godley, Hyman Minsky, and James Tobin. With some simplification - in particular, with respect to the microfoundations - their theories are presented as different "closures" of the same SFC model. The translation of the views (more or less formalized in their original version) of these authors into an SFC model, both in its accounting part and in its behavioral equations and closures, requires a thorough theoretical analysis_- which is the core of the paper together with the thesis that "the stock-flow consistent approach to macroeconomic modeling (SFCA) is a natural 'outcome' of

\footnotetext{
${ }^{16}$ Referring to the variables of the model, this rules can be phrased simply saying that the nth variable must be logically implied by the n-1 variables of the system, or more extensively, "if there are M columns and N nonordinary rows in the transactions matrix, then there are only $(\mathrm{M}+\mathrm{N}-1)$ independent accounting identities in the model. Due to this principle, highly similar to Walras' Law, one equation must be kept out" (Le Heron and Mouakil 2008).

17 The author does not present the simulated solutions of the models merely for lack of space, hence it was not his intent to develop an "unsolved" model; however, we believe this paper represents a good example of what we defined as an SFC model with a discursive solution, since it reaches highly interesting conclusions, without referring to the solution of the model.
} 
the path taken by Keynesian macroeconomic thought in the 1960s and 1970s" (Dos Santos 2006, p. 251, abstract). A similar position is taken by Lavoie (2008b), who identifies in the SFC approach a possible locus for the reconciliation of the Fundamentalist (American) PostKeynesians, and the Cambridge Post-Keynesians. The higher interest of the first of the two groups in the monetary and financial side of the economy, and the deeper focus of the second group on the real side, in the eye of the authors, can be integrated into this modeling framework, which allows us "to entertain both monetary and real issues within a single model" (Lavoie 2008b, p.15).

The possibility of formally tracking the source and the end of economic flows makes this approach particularly powerful and fruitful when applied to the analysis of monetary theories. The pioneering work in this direction is Lavoie (2004), in which the author elucidates the different stages — under different banking systems — of the monetary circuit (see Graziani 2003) relying on the transaction and revaluation matrices. Zezza (2012) follows the road traced by Lavoie, and uses the SFC approach to tackle specific puzzles of the circuitist literature. The "paradox of profits" is such that in a credit economy, in a single period, the revenues of firms can at most equal the initial finance received for production costs and they do not cover interest payment. The accounting framework allows Zezza to show how, taking into account banks' profits in an attempt to consistently model the banking sector, the initial finance can be considered to include interest payment. Bellofiore and Passarella (2010) do not enter directly into the theoretical debate on the possible relation between SFC and the monetary circuit. The two authors, in a wider effort to adapt the Financial Instability Hypothesis (FIH) by Minsky to the current economic system, create an SFC model to reproduce a financialized version of the monetary circuit. The main differences are (1) money can now enter the circuit also through households' demand for loans and (2) the creation of derivatives is stimulated by the growing bulk of savings of non-financial firms. Passarella (2012) deepens the investigation on the formalization of the theory of Minsky. The author builds an SFC model with the aim of analyzing the $\mathrm{FIH}$, highlighting its flaws — both theoretical and empirical — and proposing modifications to make it coherent with the new evidence emerging with the subprime crisis. A possible development of the literature in this direction is the one suggested by Morris and Juniper (2012), according to which the SFC approach might allow for a synthesis between the Modern Money Theory and the analysis of Hyman P. Minsky. 
Among the authors who used the SFC approach in this way (hence, employing the first and second step to develop a theoretical discussion), Michell and Toporowski (2012) put forward an interesting perspective. They start from what they define as a "classical" system ${ }^{18}$ to build an increasingly complex model (still remaining on a high level of simplification) to make explicit the role of different sources of finance. The peculiarity lies in the conclusions they reach, which are critical with the SFC approach, as they underline how the lack of inter-sectoral flows dismiss the possibility of representing important features of active financial markets.

\section{THEORETICAL MODELS, SIMULATION RESOLUTION}

The vast majority of SFC papers are numerically simulated. ${ }^{19}$ This section presents an attempt to review the most important contributions of simulated models, organized according to their subject. We identified three main topics: financialization, open economies, and policy. It is selfevident that these classifications are subjective, and boundaries are not often totally neat-e.g., it is possible to identify policy indications in almost all the papers analyzed. This classification has, indeed, an organizing scope limited to the needs of our paper.

\subsection{Financialization}

Probably the main advantage of the social accounting approach to money flows is its possibility to integrate the real and the financial side of the economy. The accounting framework can be adapted to reproduce virtually any level of complexity (as, for any model, one must face a tradeoff between realism and handiness). Sources of financing, portfolio choices, consumption and investment decisions, and so on, can all be included in the same model. Furthermore the SFC framework presents an interesting modeling feature in that it explicitly accounts for capital gains. The variation in value and in quantities of an asset (say bonds) may be divided into two components; the variation due to the emission of bonds and the capital gain (or loss) due to the change in the price level (1). ${ }^{20}$ When modeling a sector holding financial assets, it is important

\footnotetext{
${ }^{18}$ Defined as a system "in which firms borrow in order to invest in new capital, all saving takes place in the household sector, and the only form of financial assets are bank deposits and loans system" (Michell and Toporowski 2012, p. 3).

${ }^{19}$ In order to prove the scientific validity of the results presented in simulated papers, it is now the norm to publish the code of the model. The website www.sfc-models.net contains a large selection of these codes (on top of bibliographic references), allowing the newcomer to find a good starting point.

${ }^{20}$ Godley and Lavoie (2007c, p. 135) use an ingenious diagram, the so-called Ostergaard diagram, to explain how capital gains are accounted for.
} 
to account for capital gains and add (or remove in the case of a loss) them from the desired variation in quantities held of that asset, otherwise the variation in stock is not explained by the flows and the model is no longer consistent.

$$
\Delta\left(p_{B L} B L\right)=p_{B L} B L-p_{B L,-1} B L_{-1}=(\Delta B L) p_{B L}+\left(\Delta p_{B L}\right) B L_{-1}
$$

In (1), $(\triangle B L) p_{B L}$ is equal to the new investment in that asset- that is, the increase in quantity held times its price. However, because the price has changed, the nominal variation in asset held is equal to the new investment plus capital gains. We thus have, in general, that the wealth of a sector in period $t$ is equal to the wealth of that sector in period $t-1$ plus savings plus capital gains (2).

$$
V_{t}=V_{t-1}+\operatorname{sav}_{t}+C G_{t}
$$

All these features made SFC modeling a valuable tool in the recent economic debate on financialization and in the analysis of the financial crisis, which started in the US in 2007.

The concept of financialization has been thoroughly investigated in the heterodox tradition, and different aspects have been at the center of the analysis of different authors (see, among others, Bhaduri 2011, Dumenil and Levy 2011, and Onaran, Stockhammer, and Grafl 2011). Similarly, the SFC contributions to this topic tend to focus on specific aspects of the problem. Lavoie (2008a) expands the model of the second chapter of Godley and Lavoie (2007c) to include further financial aspects.

Firms are assumed to borrow in order to finance inventories, while investments are financed through retained profits and equities. Households borrow money to consume, and banks set the interest rate according to the liquidity measure they want to reach. The effects of financialization are analyzed through four simulations representing changes in the financial behavior of firms and households (i.e., firms' equity issued and retained profits, and households' desire to hold equities and demand for loans), and two simulations representing the current financial crisis (i.e., lower loans and profit margins of banks). Zezza (2008) also expands a previous paper (Dos Santos and Zezza 2004) to include the new evidence emerging from the 2007 subprime mortgage crisis. Therefore, households are differentiated between the top 5 percent of earners and the rest, and the housing market is explicitly considered.

A more specific approach is developed by van Treeck (2009), whose focus is on shareholder value orientation. The model includes several features typical of the debate over financialized economies. Next to the degree of capacity utilization, the determinants of 
investment decisions are the Tobin $q$, the retention rate, and the leverage. Furthermore, households become indebted to consume. The role of shareholder value orientation is assessed via two main simulations: a change in the proportion of equity issued and an increase in the dividends payout rate. The results are in line with empirical evidence (a negative correlation between investment and shareholder orientation), but sensitive to changes in parameters; in particular, they depend on the relative strength of the wealth and debt effects.

Le Heron (2012a, forthcoming) focuses on the state of confidence as a transmission channel of the crisis, from the US to the French economy. The state of confidence enters the model influencing both firms in their investing decisions and banks in their financing decisions. The author, in his analysis of the crisis, recalls the theory of Minsky, and individuates in the borrower's risk and lender's risk key variables in the decision of the sectors. In particular, he accounts for the possibility of a credit rationing by banks toward firms. The economy is tested for changes in confidence parameters, reaction to financial and monetary policy, and (in the 2012a paper) for changes in income distribution. The analysis of Minsky returns and becomes central in Ryoo (2010). His model reproduces short- and long-wave cycle dynamics. The interaction between aggregated demand and the labor market determines the first, while the long waves are the result of an endogenous Minskyan dynamic, driven by the ratio of profit to debt service commitments, and lead to crisis. A further interesting feature of the paper is that, next to the standard simulation resolution, it presents an analytical one. This allows for understanding the dynamic of the model without the need to rely on the value of parameters (which involves several problems).

We decided to include Clévenot, Guy, and Mazier (2009) as the last paper in this section, as it follows a different methodology from the other works on financialization presented here. As a matter of fact, the model serves for macro-econometric analysis and does not present a simulated solution. The issue of financialization is accounted for as an increase of financial assets in the balance sheet of non-financial firms. The determinants of the level of equity issued and loans demanded by firms are empirically tested for the French economy. Equity issued appears positively correlated with the real rate of interest, the economic rate of profit, and the level of indebtedness at the end of the previous period. While, according to the paper, the level of indebtedness is negatively correlated with the real rate of interest and the economic rate of profit, whereas positively correlated with the level and rate of accumulation of capital and the equities rate of return. 


\subsection{Open Economies}

The stock-flow consistent framework is well known for two main original features: the Tobinesque representation of portfolio choice and Godley's analysis of world imbalances. It is thus natural that many SFC models represent open economies and examine open economies' issues. This section will go through what we retain as the three phases to open economy modeling within the SFC framework. The first phase corresponds to Godley's seminal whistle blowing of world imbalances at the turn of the century. The second one is composed of the papers constructing the formal representation of open economies within the SFC literature, ending with the chapters 6 and12 of Godley and Lavoie (2007c). The last phase is made up of all the papers analyzing particular points of the real world, based on the formal representation described in the second phase. These analyses, as we will see, are based on two main arguments: (1) the European construction and its monetary union, and (2) financialization, world imbalances, exchange rate, and foreign reserves, among others.

Godley famously used flow-of-funds accounts to analyze the turbulent phase of the turn of the century (Godley 1999b). He rightly pointed out the increasing risk that was developing in the US economy, identifying seven unsustainable processes:

(1) the fall in private saving into ever deeper negative territory, (2) the rise in the flow of net lending to the private sector, (3) the rise in the growth rate of the real money stock, (4) the rise in asset prices at a rate that far exceeds the growth of profits (or of GDP), (5) the rise in the budget surplus, (6) the rise in the current account deficit, (7) the increase in the United States' net foreign indebtedness relative to GDP. (Godley 1999b, p. 2)

He then repeated the analysis in 2004 (Godley and Izurieta 2004), followed by other authors at the Levy Institute of Bard College (see Papadimitriou, Zezza, and Hannsgen 2006; Godley et al. 2007; Zezza 2009, among others). The rise of the crisis has shed light on the methodology, which compelled more mainstream economists and institutions to use it; see Bê Duc and Le Breton (2009), Barwell and Burrows (2011), and Zezza (2009) for statements on the use of flow-of-funds. The analysis undertaken not only concerned the US, but also Europe, as in Semieniuk, van Treeck, and Truger (2011). This empirical use of the SFC framework has been further developed at the Levy Institute, where a more complex and complete empirical world model has been designed. See Section 5 for further discussion of empirics in the literature.

Apart from empirical analysis, a more formal representation of open economies inside the SFC framework has been developed, starting with Godley and Zezza (1989), describing the 
Danish economy. Godley (1999a) presents the first formal model, to our knowledge, of an open economy. The works of Godley and Lavoie (2003), Taylor (2004a), and Godley and Lavoie (2006) have led the way toward the two models described in Godley and Lavoie (2007c). Most of the modeling features concern the exchange rate dynamics and expectations, but aspects such as foreign reserves, gold reserves, balances of payments, and others are also addressed.

Analysis of occurring world events was then conducted based on this formal model. Among these events, the European construction and its monetary union have attracted many analyses. Godley and Lavoie (2007a) concentrate on dynamics of a three-country model with two currencies. They show how traditional results such as a "twin deficit" do not hold within the eurozone and how the quasi-stationary state emerging from shocks might lead to exploding situations, depending on the European Central Bank's (ECB) behavior. They use this analysis to criticize the Maastricht Treaty and the successive Stability and Growth Pact. Duwicquet and Mazier (2010) analyze the stabilization effects of foreign asset holding and intra-zone credit, using a two-country model with one shared currency model. They conclude that a foreign asset model might mitigate asymmetric shocks, but only with a smaller effect than usually accounted, while foreign loans have no effect whatsoever. Khalil and Kinsella (2010) also analyze financial integration, but rather work on three different levels of integration: autarky, free trade, and monetary union. They conclude that policies promoting financial integration might have clear positive impacts if executed with fiscal and monetary policies. Kinsella and Khalil (2011) simulate the macroeconomic effect of a small open economy experiencing a debt deflation. They consider two different cases: in the first one, the economy is within a free-floating exchange rate; in the second, the economy is in a monetary union. Their simulations show that being in a monetary union prolongs and extends the debt deflation of the small open economy. Duwicquet, Mazier, and Saadaoui (2012) offer an analysis of the implicit transfers occurring within the eurozone due to exchange rate misalignment. Their model is composed of two countries, south and north, where the southern country is suffering from an over-evaluated euro, given its balance of payments and capital account, implying that it faces more difficulties to export, while the northern country enjoys an under-evaluated euro, boosting its exports. The authors then propose various policies in order to counter these implicit transfers from the south 
to the north: a federal budget with three different levels of federalism ${ }^{21}$ and a system of eurobonds. They show that the eurobonds system is equivalent to a federal budget with part of the implicit transfers being countered by explicit transfers on top of fiscal transfers.

The second strand of theoretical models regarding open economies focuses on exchange rate regimes and foreign reserve movements. Izurieta (2003) analyzes the case of dollarization as a response to financial instability. His model, an early version of (Godley and Lavoie 2007c, chapter 6), shows how a "dollarized" economy facing an exogenous shock will have to give up counter-cyclical policies to keep financial stability. He concludes that the dollarized economy thus traded income and employment protection for financial stability. Lavoie and Zhao (2010) study two scenarios of Chinese reserve diversification using a three-country (China, Euroland, US) model with different exchange rate policies: fixed renminbi-dollar parity and a floating euro-dollar exchange rate. They conclude that the diversification of Chinese reserves toward euros will be detrimental to Euroland in any case, but that a gradual diversification will imply a less harmful initial shock even if stabilizing a worse situation for Europe. This highlights the path dependency of their model's steady state, an interesting feature which was discussed in Section 2.2. Lavoie and Daigle (2011) investigate exchange rate expectation, using a twocountry model. The innovation in their paper is that they include expectation formation on the exchange rate. They allow for two different behaviors: chartist or conventionalists. The former behavior builds exchange rate expectation on trends, the latter on a fundamental value. They conclude that exchange rate expectations are a source of persistence in the model and that, depending on the share of chartists in the population, the exchange rate might be stabilizing or not. Mazier and Tiou-Tagba Aliti (2012) add prices into the picture presented in Lavoie and Zhao (2010). They analyze exchange rate regimes under inflationary pressures. Their model is composed of three economies with different exchange rate regimes: fixed, managed, and floating. Furthermore, they allow for countries to have inflation. They show that having flexible prices might mitigate the results obtained in Lavoie and Zhao (2010).

\subsection{Policy Indications}

This section represents a macro area of research. Several of the papers presented in the other sections include, as well, an analysis of policy implications. We choose not include them in this

\footnotetext{
${ }^{21}$ (1) Only fiscal transfers, (2) fiscal transfers and part of the implicit transfers countered by explicit transfers from the north to the south, and (3) fiscal transfers and implicit transfers fully compensated by explicit transfers.
} 
section because we believed other aspects of the papers were distinctive or more relevant to our categorization.

The methodology used to analyze policy implications is common to most aggregated macro models. Once a stationary or a steady state - depending on whether the model is a growth model or not-is identified, the model is shocked. That means that the value of either one of the exogenous variables or of the parameters is changed according to the policy one wants to reproduce. It is then possible to see how the economy reacts. If it reaches a new stationary or steady state, it can be compared with the initial position. Contrarily, if it presents an explosive behavior, the modeler can try to identify the causes of the unsustainable processes. The authors, trying to elucidate the effects of a policy, can either attempt to individuate some relation potentially valid in any capitalist economy using a more theoretical approach, or refer to a particular economy with a more empirical approach. In the former case, the model is usually built so as to reproduce the characterizing features of the economy investigated.

The majority of the papers using a theoretical approach to the analysis of policies evolved mainly around the comparison between fiscal and monetary policy. Dos Santos and Zezza (2004) extend Lavoie and Godley (2002) and, including the public sector-that is, the central bank and government - show how fiscal policy is more effective than monetary policy, since an increase in the interest rate has two contrasting effects: a negative impact on the real side of the economy inhibiting investment, and a positive one on financial inflows and expenditure of asset holders. Godley and Lavoie (2007b) challenge the New Consensus support for monetary policies as an instrument to reach full employment (only in the short run and not taking into account fiscal policy). Their model shows that "fiscal policy can deliver sustainable full employment at a target inflation rate within an SFC framework with some arbitrary interest rate" (Godley and Lavoie 2007b, p. 99). The relation between these two policies has been further and systematically investigated by Le Heron (2012b). His analysis springs from the attempt to analyze the effects of the monetary policy, netting out the effects of the fiscal one, and reaches the conclusion that the latter can never be neutral due to the high amount of transmission channels. The effects of the policies were at the center of the analysis of previous works by the author (see Le Heron 2009 and Le Heron and Mouakil 2008, which focus in particular on the reactions of the banking sector).

Arestis and Sawyer (2012) enter this debate using the same methodology based on 
shocking the system to investigate how the modeled economy reacts to a fiscal, monetary, or mixed policy. The unique characteristic of the paper is that it is based on the Levy model (more on this in Section 5). Their results show the importance of fiscal policy, which they suggest should take a leading role in driving aggregate demand.

The understanding of recent or actual economic events and a critical examination of the related implemented policies is undoubtedly one of the core activities of the economists. SFC practitioners do not differ in that. So Ryoo and Skott (2011) enter the very actual debate over austerity. In their paper, full employment is considered to be the final goal of policies, and counter-cyclical spending appears to be an effective policy in the event of a shortage of aggregated demand, even if it might lead to unstable growth. Their point is that active fiscal policies work better then austerity in bringing the economy back to stability. The dynamics of the model are investigated through both simulation-based and analytical results. Chatelain (2010) also focuses on the latest events and offers an analysis of how capital shortage and financial constraints may evolve at a different pace for a growing economy shocked by either a fall of public expenditures or a rise of the interest rate. By allowing credit constraints to take place and tempering investments otherwise driven by the capacity utilization rate, Chatelain shows that four different regimes may emerge: the traditional wage-led and profit-led, and two mixed regimes. According to the author, credit constraint may emerge by either a decrease in the rate of profits or an increase in the interest rates. The analysis shows that supply-side policies have a later impact than demand-side policies, and thus depending on the shock and on the fiscal constraints (e.g., the Maastricht Treaty), some policies might be less efficient than others to restore growth.

We conclude this section with the paper by Oreiro and Lobo (2012), which offers an original contribution since the analysis of the two authors on the effects of fiscal and monetary policies is based on a model built to specifically ${ }^{22}$ reproduce the Brazilian economy. ${ }^{23}$ Affecting the structure of the model, this has important consequences on its results: the considerations of

\footnotetext{
${ }^{22}$ For an economy-specific approach, a great contribution has been offered by several French authors, as highlighted in Section 6.

${ }^{23}$ As such, it includes two kinds of government bonds: pre-fixed and post-fixed, the first one being those whose yield is known when the title is purchased, while for the second one the return depends partially or entirely on indexes - such as discount rate-which might vary before the title gets to maturity. The simulations show that elimination of this second kind of bonds leads to more stable growth. Furthermore, in an economy where the distributive conflict is so deep, monetary policy seems like a second-best solution to tackle inflation in comparison to policies directed at solving distributional problems.
} 
the monetary policy depend, in part, on the distributional problems of the country.

\subsection{Theoretical Debate: Looking for Consensus}

In the words of one of the authors who most contributed to the rise and diffusion of the SFC approach, the SFC modeling approach provides a potential for common ground for all heterodox schools, just like the maximizing representative agent seems to be the standard of mainstream economics. Stock-flow consistency as defined here fulfills what Pasinetti (2005: 841) calls one of the constructive features of the Cambridge School of Keynesian economics - the need for internal consistency, and not only formal rigor. (Lavoie 2008a)

The economic debate (in particular, the heterodox one, which lacks a universally accepted modeling framework) can largely benefit from the development of such common ground, which may allow for easier comparison among theories and interpretations. The solid and comprehensive economic theory, which heterodox economists aim to build to challenge the current mainstream, might become a Babel Tower without the support of a common language. Next to Dos Santos (2006) (see Section 3), several authors have started to rephrase existing theories through SFC models and others have started presenting their contributions to the theoretical debate basing their analysis on this structured framework. A perfect example in this direction is Lavoie and Godley (2002). The two authors develops Kaldor's "neo-Pasinetti” model to further include the source of finance ${ }^{24}$ for firms. The model is characterized by several Kaleckian and Kaldorian features, and enters the Post-Keynesian theoretical debate of the growth model (with a further focus on capacity utilization), relying on the solid ground of stockflow consistency. Dallery and van Treeck (2011) develop the analysis of capacity utilization by Lavoie and Godley (2002), showing that when different interests of different groups are taken into account, the equality between actual and standard rate of capacity utilization is not a necessary outcome in the long-run equilibrium. Simulations are run to represent different eras of capitalism with different interests prevailing: a Fordist era with managers and workers as leading groups and adjusting profitability targets, and a Financialization era with fixed profitability goals. A lucid contribution in the research for systematization of Post-Keynesian theory using SFC modeling as a common structured ground is represented by Dos Santos and Zezza (2008). In an attempt to create a benchmark for future works, the two authors associate to practically each step of the model a theoretical explanation that places their modeling choices in

\footnotetext{
${ }^{24}$ In the original paper (Kaldor 1966), households were supposed to hold their wealth only in equities.
} 
the wider theoretical economic debate. Several subjects are hence investigated and analyzed, such as capacity utilization, investment decisions, asset prices, and consumption decisions. Furthermore, we believe it is interesting to notice that the paper presents an analytical solution of the model to allow for an easier and deeper understanding of its characteristics. A similar approach is the one used by Sarquis and Oreiro (2011), who develop a Post-Keynesian model for open economies based on a thorough theoretical analysis, with the aim of demonstrating that the Post-Keynesian approach is a valid and coherent alternative to current economic orthodoxy. A very significant example of this branch ${ }^{25}$ is represented by Le Heron (2008). The author tries to reconcile two monetary theories normally considered to be rather antithetical: on the one hand, exogenous money with endogenous interest rate; and on the other hand, endogenous money with exogenous interest rate. To reach its goal, the paper focuses on banks' state of confidence (lender's risk) as well as on the distinctions between short-run and long-run interest rates, which the author formally puts forward in his model.

Other authors used the SFC modeling approach to tackle specific subjects. Zezza and Dos Santos (2006), who enter the traditional - at least in the heterodox research agenda — debate on income distribution, develop a growth model with a rich financial structure. Their results show that the economy is demand-led and the paradox of thrift holds, as an increase in investment slows growth. Furthermore, while an increase in tax unequivocally has a depressing effect on the economy, the effects of the attempt by the other sectors (bank and firms) to increase their share of income depends on the choice of parameters. The income distribution is also the focus of the two-sector SFC model developed by Hoon Kim (2006). His demand-led economy validates both the "paradox of thrift" and the "paradox of costs" (higher costing margins - hence lower real wages - do not lead to an increase in profit, but cause a decrease in output). The model includes several specifications in its real side, among which are target-return pricing, conflicting-claims inflation, and endogenous labor-saving technical progress.

Dafermos (2012) tries to fill what he seems to consider a gap in the SFC literature: "an integrated consideration of the macroeconomic implications of liquidity preference and uncertainty is still lacking in the SFC literature." The model succeeds in reproducing a recessionary process, thanks to its characteristic of simultaneously taking into account the liquidity preferences of households, firms, and banks.

\footnotetext{
${ }^{25}$ Which we might call "consensus-making theoretical simulated models."
} 


\section{EMPIRICAL MODELS}

As seen in Section 4.2, the work of Godley on empirical analysis of unsustainable processes has shed light on the need to build empirical models to be used as a structured tool for economic predictions. We will not repeat here the historical development path of these models; we will rather concentrate on the methodological aspects of the existing literature.

To our knowledge, only two groups of authors have been working on "fully" empirical ${ }^{26}$ models. ${ }^{27}$ Godley, Zezza, and authors related to the Levy Institute (hereafter the Levy model; see, among others, Godley and Zezza 1989; Zezza 2009, 2011; Papadimitriou, Hannsgen, and Zezza 2011) and Kinsella and Tiou-Tagba Aliti (hereafter the Limerick model; see Kinsella and Tiou-Tagba Aliti 2012). It is also worth mentioning the work of Clévenot, Guy, and Mazier (2009, 2010), who estimate the parameters basing their econometric analysis on their own model. However, no simulation has been conducted based on these estimated values. The way in which these fully empirical models are estimated/calibrated differs. On the one hand, the Levy model assumes fixed parameters estimated using econometrics. On the other hand, the Limerick model estimates fixed parameters only when necessary (if there is more than one parameter per independent equation) and calibrates the others. ${ }^{28}$ This difference is fundamental since the Levy model allows us to predict future variations, while the Limerick model allows us only to conduct simulations on past data. ${ }^{29} \mathrm{SFC}$ models explicitly account for the discrepancies between ex-post realizations, which are given on the one hand by statistical accounting equilibriums (every spending of someone is the income of someone else), and on the other, are the result of modeled behaviors based on ex-ante values. These discrepancies are incredibly relevant in that they represent dynamical adjustment processes such as capital gains.

\footnotetext{
${ }^{26}$ We distinguish fully empirical models from empirical models in the following way: fully empirical models not only estimate all their parameters, but also apply their model to predict variation in endogenous variables based on different scenarios, starting from the present state of economy. Empirical models extract stylized facts from empirical data and then conduct simulations on the impact of these facts. The simulations start from a steady state that is not necessarily connected to the present situation. These models based on stylized facts are analyzed in Section 4.

${ }^{27}$ Davis (1987a, b) also developed an econometric SFC model for the UK. Since our paper focuses on "modern" SFC models, these papers will not be discussed here.

${ }^{28}$ We define estimation as when a parameter is assumed constant over a time span and estimated using econometric methods such as Ordinary Least Squares (OLS), maximum likelihood, etc. Calibration is the process of finding a value for each parameter, in each period, such that the model replicates the data set. In that sense, calibration has no predictive power since it does not give any insight on parameters' future values. However, filtering techniques can be used on these calibrated parameters in order to obtain a trend and thus predict future values.

${ }^{29}$ Kinsella and Tiou-Tagba Aliti (2012) talk about Dynamic Empirical Simulation.
} 
Godley and Zezza (1989) is the one of the first empirical uses of an SFC model ${ }^{30}$ that we know of. It presents a simple model of a small open economy applied to Danish data. The model is then estimated and used to draw some medium-term forecasting. The subsequent works of the Levy Institute are based on a more developed model, applied to US data, and used for predictions - which, it is worth noting, have been fairly good. They have been consistently warning, since Godley's unsustainable processes in 2001, about the risk of financial crises. However, while Godley in the 1980s and others afterward have been using balance sheets and flow-of-funds analysis to observe imbalances and rising instability, the Levy model is the first one to be able to make some predictions in a more systematic way, since it allows for comparison of different scenarios resulting from different policies.

The Limerick model is still under construction and Kinsella and Tiou-Tagba Aliti (2012) is still a working paper, however it gives us sufficient insight into their work. There are two main differences in the approach and in the data used when compared with the Levy model. First of all, the Limerick model is based on the balance sheets of the Irish economy and is thus based on stock data, while the Levy model is based on stock and flow data. Second, as already expressed, the Limerick model is calibrated over the data set used. The model, even if still rough, already allows us to simulate changes in policies in the past and see the impact they would have had if implemented.

The paucity of empirical models shows, in our understanding, the difficulty and probably the controversy in estimating the parameters of the behavioral equations (see Section 2.1 and Taylor 2008). A word should be said on the proliferation of parameters. Indeed, more parameters allow for the representation of more subtle behaviors. However, this is at the cost of more complexity when trying to estimate or analytically solve the model. If one believes that SFC modeling should be used merely as a reference within an argumentative theoretical debate (see Section 3), or for simple didactical purposes, a just balance between realistic behaviors and the number of parameters has to be found. This joins the call of Dos Santos and Zezza (2008), among others, for simple models targeted at specific subjects, rather than large models including numerous sectors or assets.

\footnotetext{
${ }^{30}$ The first empirical SFC model is Godley and Zezza (1986).
} 


\section{CONCLUSION AND THE WAY FORWARD}

The primary goal of this paper was to depict the state of the art of SFC models. To reach our goal, we divided the main publications we gathered according to their subjects and methodology. This not only provides a more structured overview of the literature, but allows as well for some conjecture on the possible lines of development of this class of model.

1. If one believes in the importance of micro foundation, the ABM-SFC model represents an alternative to DSGE, and is more solid since it does not include fallacies of composition (see Section 2.3).

2. SFC models can provide a useful tool in the consensus-making attempt within the PostKeynesian tradition, since the theoretical discussion and the comparisons are based on a coherent, structured, and at the same time adaptable framework (as shown in Section 4.4).

3. Empirical and policy indications models, combined, can lead to an economy-specific analysis, which is more useful at the policy level. We have read a few articles, ${ }^{31}$ still very preliminary, that seem to go in that direction. We believe that this approach to SFC modeling should be pursued.

4. The possibility of modeling the financial side of the economy has represented an incentive in developing models including complex financial sectors. This has its counter part in the real side, which we feel has been a bit overlooked and could be further investigated. Among others, a direct benefit would be a more complete understanding of the interdependences between the two sides of the economy.

We wish to conclude with a personal consideration. We encourage a didactical use of SFC models, since we believe that their completeness can ease the comprehension of economic dynamics and interdependencies. To this end, both more complete empirical and simulated models and simple theoretical models with analytic solutions (see Dos Santos and Macedo e Silva 2009), can represent useful tools.

\footnotetext{
${ }^{31}$ The conference, "Political Economy and the Outlook for Capitalism," held in Paris in July 2012, gathered the largest group of SFC modelers so far.
} 


\section{REFERENCES}

Arestis, P. and M. Sawyer. 2012. "The Effectiveness of Fiscal Policy in the Levy Institute's Stock Flow Model." In D. B. Papadimitriou and G. Zezza (Eds.), Contributions in StockFlow Consistent Modeling: Essays in Honor of Wynne Godley. Houndmills, Basingstoke, Hampshire: Palgrave Macmillan.

Backus, D., W. C. Brainard, G. Smith, and J. Tobin. 1980. "A Model of U.S. Financial and Nonfinancial Economic Behavior.” Journal of Money, Credit and Banking 12 (2): 259293.

Barwell, R. and O. Burrows. 2011. "Growing Fragilities? Balance Sheets in the Great Moderation." Financial Stability Paper No. 10. London, UK: Bank of England.

Bê Duc, L. and G. Le Breton. 2009. "Flow-of-Funds Analysis at the ECB: Framework and Applications." Occasional Paper Series No. 105. Frankfurt, Germany: European Central Bank.

Bellofiore, R. and M. Passarella. 2010. "Minsky, the Monetary Circuit and the Current Crisis: A SFC Monetary Accounting Framework." Paper presented at Can It Happen Again? Sustainable Policies to Mitigate and Prevent Financial Crises, conference at the University of Macerata, Italy. October 1-2.

Bezemer, D. J. 2011. “Causes of Financial Instability: Don’t Forget Finance.” Working Paper Series No. 655. Annandale-on-Hudson, NY: Levy Economics Institute of Bard College.

Bhaduri, A. 2011. "A Contribution to the Theory of Financial Fragility Crisis." Cambridge Journal of Economics 35 (6): 995-1014.

Borrill, P. L. and L. Tesfatsion. 2010. "Agent-Based Modeling: The Right Mathematics for the Social Sciences?” Working Paper No. 10023. Ames, IA: Department of Economics, Iowa State University.

Chatelain, J. 2010. "The Profit-Investment-Unemployment Nexus and Capacity Utilization in a Stock-Flow Consistent Model." Metroeconomica 61(3): 454-472.

Clévenot, M., Y. Guy, and J. Mazier. 2009. "Equity and Debt in a Financialised Economy: The French Case.” CEPN Working Papers. http://hal.archives-ouvertes.fr/hal-00435685/.

- 2010. "Investment and the Rate of Profit in a Financial Context: The French Case." International Review of Applied Economics 24(6): 693-714.

Cohen, J. 1972. "Copeland's Moneyflows after Twenty-Five Years: A Survey.” Journal of Economic Literature 10(1): 1-25.

Copeland, M. A. 1949. "Social Accounting for Moneyflows." The Accounting Review 24(3): 254-264. 
Dafermos, Y. 2012. "Liquidity Preference, Uncertainty, and Recession in a Stock-Flow Consistent Model.” Journal of Post Keynesian Economics 34(4): 749-775.

Dallery, T. and T. van Treeck. 2011. "Conflicting Claims and Equilibrium Adjustment Processes in a Stock-Flow Consistent Macroeconomic Model." Review of Political Economy 23(2): 189-211.

Davis, E. P.1987a. “A Stock-Flow Consistent Macro-Econometric Model of the UK Economy_Part I." Journal of Applied Econometrics 2(2): 111-132.

_ 1987b. "A Stock-Flow Consistent Macro-Econometric Model of the UK EconomyPart II." Journal of Applied Econometrics 2(4): 259-307.

Denizet, J. 1967. Monnaie et Financement, Essai de Thèorie dans un Cadre de Compatibilité Économique. Dunod, Paris.

Dos Santos, C. H. 2005. “A Stock-Flow Consistent General Framework for Formal Minskyan Analyses of Closed Economies." Journal of Post-Keynesian Economics 27(4): 712-735.

- 2006. "Keynesian Theorizing during Hard Times: Stock-Flow Consistent Models as an Unexplored Frontier of Keynesian Macroeconomics." Cambridge Journal of Economics 30(4): 541-65.

Dos Santos, C. and A. C. Macedo e Silva. 2009. "Revisiting (and Connecting) Marglin-Bhaduri and Minsky: An SFC Look at Financialization and Profit-led Growth." Working Paper No. 567. Annandale-on-Hudson, NY: Levy Economics Institute of Bard College.

Dos Santos, C. H. and G. Zezza. 2004. "The Role of Monetary Policy in Post-Keynesian StockFlow Consistent Macroeconomic Growth Models: Preliminary Results.” In M. Lavoie (Ed.), Central Banking in the Modern World: Alternative Perspectives. Cheltenham: Edward Elgar.

— 2004. "A Post-Keynesian Stock-Flow Consistent Growth Model: Preliminary Results." Working Paper No. 402. Annandale-on-Hudson, NY: Levy Economics Institute of Bard College.

—. 2008. "A Simplified, Benchmark, Stock-Flow Consistent Post-Keynesian Growth Model." Metroeconomica 59(3): 441-78.

Dumenil, G. and D. Levy. 2011. "Modeling Monetary Macroeconomics: Kalecki Reconsidered." Metroeconomica 63(1): 170-199.

Duwicquet, V. and J. Mazier. 2010. "Financial Integration and Macroeconomic Adjustments in a Monetary Union.” Journal of Post Keynesian Economics 33(2): 333-370.

Duwicquet, V., J. Mazier, and J. Saadaoui. 2012. "Exchange Rate Misalignments, Fiscal Federalism and Redistribution: How to Adjust in a Monetary Union." Preliminary paper presented at the $9^{\text {th }}$ EUROFRAME Conference on Economic Policy Issues in the European Union, Kiel, Germany. June 8. 
Epstein, J. and R. Axtell. 1996. Growing Artificial Societies: Social Science from the Bottom Up. Washington, DC: MIT Press and Brooking Press.

Godley, W. 1996. "Money, Finance, and National Income Determination." Working Paper No. 167. Annandale-on-Hudson, NY: Levy Economics Institute of Bard College.

- 1997. "Macroeconomics without Equilibrium or Disequilibrium." Working Paper No. 205. Annandale-on-Hudson, NY: Levy Economics Institute of Bard College.

— . 1999a. "Open Economy Macroeconomics Using Models of Closed Systems." Working Paper No. 285. Annandale-on-Hudson, NY: Levy Economics Institute of Bard College. 1999b. Seven Unsustainable Processes: Medium-Term Prospects and Policies for the United States and the World. Strategic Analysis. Annandale-on-Hudson, NY: Levy Economics Institute of Bard College.

Godley, W. and F. Cripps. 1983. Macroeconomics. Oxford, UK: Oxford University Press.

Godley, W. and A. Izurieta. 2004. Balances, Imbalances and Fiscal Targets: A New Cambridge View. Seminar Paper. Cambridge, UK: The Cambridge Endowment for Research in Finance (CERF), February.

Godley, W. and M. Lavoie. 2003. "Two-Country Stock-Flow-Consistent Macroeconomics Using a Closed Model within a Dollar Exchange Regime." Finance Working Paper No. 10. Cambridge, UK: The Cambridge Endowment for Research.

—. 2006. "Comprehensive Accounting in Simple Open Economy Macroeconomics with Endogenous Sterilization or Flexible Exchange Rates." Journal of Post Keynesian Economics 28(2): 241-276.

- 2007a. "A Simple Model of Three Economies with Two Currencies: The Eurozone and the USA." Cambridge Journal of Economics 31(1): 1-23.

- 2007b. "Fiscal Policy in a Stock-Flow Consistent (SFC) Model." Journal of Post Keynesian Economics 30(1): 79-100.

- 2007c. Monetary Economics: An Integrated Approach to Credit, Money, Income, Production and Wealth. New York, NY: Palgrave MacMillan.

Godley, W., D. Papadimitriou, G. Hannsgen, and G. Zezza. 2007. The US Economy: Is There a Way Out of the Woods? Strategic Analysis. Annandale-on-Hudson, NY: Levy Economics Institute of Bard College.

Godley, W. and G. Zezza. 1986. "A Simple Real Stock Flow Monetary Model of the Italian Economy." Working Paper. University of Cambridge. Cited in The Stock-flow Consistent Approach: Selected Writings of Wynne Godley, ed. M. Lavoie and G. Zezza (Palgrave, 2012).

—. 1989. "A Simple Real Stock-Flow Model Illustrated with the Danish Economy." 
Working Paper. Cambridge, UK: Department of Applied Economics, University of Cambridge.

Graziani, A. 2003. The Monetary Theory of Production. Cambridge, UK: Cambridge University Press.

Hoon Kim, J. 2006. “A Two-Sector Model with Target-Return Pricing in a Stock-Flow Consistent Framework.” Working Paper No. 06-01. Research on Banking International and National Systems or Networks. Ottawa, ON: University of Ottawa.

Izurieta, A. 2003. "Dollarization as a Tight Rein on the Fiscal Stance." In L-P. Rochon and M. Seccareccia (Eds.), Dollarization: Lessons from Europe and the Americas. London, UK: Routledge.

Jacob, C. 1972. “Copeland's Moneyflows after Twenty-Five Years: A Survey.” Journal of Economic Literature 10(1): 1-25.

Kaldor, N. 1966. "Marginal Productivity and the Macro-Economic Theories of Distribution: Comment on Samuelson and Modigliani." The Review of Economic Studies 33(4): 309319.

Kalecki, M. 1971. Selected Essays on the Dynamics of the Capitalist Economy. Cambridge, UK: Cambridge University Press.

Keynes, J. M. 1936. The General Theory of Employment, Interest and Money. London, UK: Macmillan.

Khalil, S. and S. Kinsella. 2010. "Simulating Financial Integration: A Stock-Flow Consistent Perspective." Unpublished.

Kinsella, S., M. Greiff, and E. J. Nell. 2011. "Income Distribution in a Stock-Flow Consistent Model with Education and Technological Change." Eastern Economic Journal 37(1): 134-149.

Kinsella, S. and S. Khalil. 2011. "Debt-Deflation in a Stock-Flow Consistent Macromodel." In D. B. Papadimitriou and G. Zezza (Eds.), Contributions in Stock-Flow Consistent Modeling: Essays in Honor of Wynne Godley. Houndmills, Basingstoke, Hampshire: Palgrave Macmillan.

Kinsella, S. and G. Tiou-Tagba Aliti. 2012. "Towards a Stock Flow Consistent Model for Ireland.” SSRN eLibrary. http://papers.ssrn.com/sol3/papers.cfm?abstract_id=2011462

Lavoie, M. 2004. "Circuit and Coherent Stock-Flow Accounting.” In R. Arena and N. Salvadori (Eds.), Money, Credit, and the Role of the State: Essays in Honour of Augusto Graziani. Aldershot, UK: Ashgate.

_. 2008a. "Financialisation Issues in a Post-Keynesian Stock-Flow Consistent Model." Intervention: European Journal of Economics and Economic Policies 5(2): 331-356. 
- 2008b. "Towards a Post-Keynesian Consensus in Macroeconomics: Reconciling the Cambridge and Wall Street Views." Paper presented at the 12th Conference of the Research Network Macroeconomics and Macroeconomic Policy, "Macroeconomic Policies on Shaky foundations - Whither Mainstream Economics?" Berlin, Germany. October 31-November 1.

. 2011. "Assessing Some Structuralist Claims through a Stock-Flow Framework.” In B.J. Moore and L.P. Rochon (Eds.), Post Keynesian Monetary Theory: Horizontalism and Structuralism Revisited: Reflections and Development. Cheltenham, UK: Edward Elgar.

Lavoie, M. and G. Daigle. 2011. "A Behavioural Finance Model of Exchange Rate Expectations within a Stock-Flow Consistent Framework." Metroeconomica 62(3): 434-458.

Lavoie, M. and W. Godley. 2002. "Kaleckian Models of Growth in a Coherent Stock-Flow Monetary Framework: A Kaldorian View.” Journal of Post Keynesian Economics 24(2): 277-311.

Lavoie, M. and M. Seccareccia. 2001. “Minsky’s Financial Fragility Hypothesis: A Missing Macroeconomic Link?” In R. Bellofiore and P. Ferri (Eds.), Financial Fragility and Investment in the Capitalist Economy: The Economic Legacy of Hyman Minsky, Vol. II. Cheltenham, UK: Edward Elgar.

Lavoie, M. and J. Zhao. 2010. "A Study of the Diversification of China's Foreign Reserves within a Three-Country Stock-Flow Consistent Model.” Metroeconomica 61(3): 558592.

Le Heron, E. 2008. "Monetary and Fiscal Policies in a Post Keynesian Stock-Flow Consistent Model." In L. Randall Wray and M. Forstater (Eds.), Keynes and Macroeconomics after 70 Years: Critical Assessments of the General Theory. Cheltenham, UK: Edward Elgar.

- 2009. "Fiscal and Monetary Policies in a Keynesian Stock-Flow Consistent Model." GEMF Working Paper 2009-01. Coimbra, Portugal: Group for Monetary and Financial Studies (GEMF), University of Coimbra.

- 2012a. "Confidence, Increasing Risks, Income Distribution and Crisis in a Post Kaleckian Stock Flow Consistent Model." Paper presented at Political Economy and the Outlook for Capitalism, conference. Paris, France. July 5-7.

- 2012b. "A Debate with Wynne Godley on the Neutrality of Fiscal Policy." In D. B. Papadimitriou and G. Zezza (Eds.), Contributions in Stock-Flow Consistent Modeling: Essays in Honor of Wynne Godley. Houndmills, Basingstoke, Hampshire: Palgrave Macmillan.

- Forthcoming. "Financial Crisis, State of Confidence and Economic Policies in a PostKeynesian Stock-Flow Consistent Model.” In L-P. Rochon (Ed.), Political Economy of Central Banking. Cheltenham, UK: Edward Elgar.

Le Heron, E. and T. Mouakil. 2008. “A Post-Keynesian Stock Flow Consistent Model for Dynamic Analysis of Monetary Policy Shock on Banking Behaviour." Metroeconomica 
59(3): 405-440.

Macedo e Silva, A. C. and C. H. Dos Santos. 2011. "Peering over the Edge of the Short Period? The Keynesian Roots of Stock-Flow Consistent Macroeconomic Models." Cambridge Journal of Economics 35(1): 105-124.

May, J. 1970. "Period Analysis and Continuous Analysis in Patikin's Macroeconomic Model." Journal of Economic Theory 2(1): 1-9.

Mazier, J. and G. Tiou-Tagba Aliti. 2012. "World Imbalances and Macroeconomic Adjustments: A Three-Country Stock-Flow Consistent Model with Fixed or Flexible Prices." Metroeconomica 63(2): 358-388.

Messori, M. and A. Zazzaro. 2004. "Monetary Profits within the Circuit: Ponzi Finance or 'Mors Tua, Vita Mea'?' Working Paper No. 200. Ancona, Italy: Department of Economics, Marche Polytechnic University.

Meyer, J. H. 1975. "The Balance Sheet Identity of the Government Financing Constraint and the Crowding out Effect." Journal of Monetary Economics 1(1): 65-78.

Michell, J. and J. Toporowski. 2012. "The Stock-Flow Consistent Approach with Active Financial Markets.” In D. B. Papadimitriou and G. Zezza (Eds.), Contributions in StockFlow Consistent Modeling: Essays in Honor of Wynne Godley. Houndmills, Basingstoke, Hampshire: Palgrave Macmillan.

Morris, N. and J. Juniper. 2012. "Modern Money Theory (MM) and Minsky: Towards a StockFlow-Consistent (SFC) Synthesis." AHE Panel on Modern Monetary Theory.

Onaran, O., E. Stockhammer, and L. Grafl. 2011. "Financialization, Income Distribution and Aggregate Demand in the USA." Cambridge Journal of Economics 35(4): 637-661.

Oreiro, J. L. and B. S. Lobo. 2012. “Gestão da Dívida Pública em um Modelo Pós-Keynesiano Macrodinâmico de Simulação com Consistência entre Estoques e Fluxos: O Caso Brasileiro." Unpublished.

Papadimitriou, D. B, G. Zezza, and G. Hannsgen. 2006. Can Global Imbalances Continue? Policies for the US Economy. Strategic Analysis. Annandale-on-Hudson, NY: Levy Economics Institute of Bard College.

Papadimitriou, D. B., G. Hannsgen, and G. Zezza. 2011. Jobless Recovery Is No Recovery: Prospects for the US Economy. Strategic Analysis. Annandale-on-Hudson, NY: Levy Economics Institute of Bard College.

Passarella, M. 2012. "A Simplified Stock-Flow Consistent Dynamic Model of the Systemic Financial Fragility in the 'New Capitalism." Journal of Economic Behavior \& Organization 83(3): 570-582.

Robinson, J. 1956. The Accumulation of Capital. London, UK: Macmillan. 
Ryoo, S. 2010. "Long Waves and Short Cycles in a Model of Endogenous Financial Fragility." Journal of Economic Behavior \& Organization 74(3): 163-186.

Ryoo, S. and P. Skott. 2011. "Public Debt and Full Employment in a Stock-Flow Consistent Model of a Corporate Economy." Economics Department Working Paper Series. Paper 134. Amherst, MA: University of Massachusetts Amherst.

Sarquis, A. M. F. and J. L. Oreiro. 2011. "Um Modelo Macrodinâ mico Pós-Keynesiano de Consistencia entre Estoques e Fluxos para uma Economia Aberta."

Semieniuk, G., T. van Treeck, and A. Truger. 2011. "Reducing Economic Imbalances in the Euro Area: Some Remarks on the Current Stability Programs, 2011-14.” Working Paper No. 694. Annandale-on-Hudson, NY: Levy Economics Institute of Bard College.

Seppecher, P., 2012a. "Monnaie Endogène et Agents Hétérogènes dans un Modèle Stock-Flux Cohérent." Paper presented at Political Economy and the Outlook for Capitalism, conference. Paris, France. July 5-7.

- 2012b. "Flexibility of Wages and Macroeconomic Instability in an Agent-Based Computational Model with Endogenous Money." Macroeconomic Dynamics 16(S2): 284-297.

Skott, P. and S. Ryoo. 2007. "Macroeconomic Implications of Financialization.” Economics Department Working Paper Series. Paper 41. Amherst, MA: University of Massachusetts Amherst.

Taylor, L.1983. Structuralist Macroeconomics: Applicable Models for the Third World. New York, NY: Basic Books.

- 2004a. "Exchange Rate Indeterminacy in Portfolio Balance, Mundell-Fleming and Uncovered Interest Rate Parity Models.” Cambridge Journal of Economics 28(2): 205227.

- 2004b. Reconstructing Macroeconomics: Structuralist Proposals and Critiques of the Mainstream. Cambridge, MA: Harvard University Press.

—. 2008. "A Foxy Hedgehog: Wynne Godley and Macroeconomic Modelling." Cambridge Journal of Economics 32(4): 639-663.

Tesfatsion, L. and K. Judd. 2006. Handbook of Computational Economics, Volume 2, AgentBased Computational Economics. North Holland, Amsterdam: Elsevier.

Tobin, J. 1982. "Money and Finance in the Macroeconomic Process." Journal of Money, Credit and Banking 14(2): 171-204.

Turnovsky, S. 1977. Macroeconomic Analysis and Stabilization Policy. Cambridge, UK: Cambridge University Press.

van Treeck, T. 2009. “A Synthetic, Stock-Flow Consistent Macroeconomic Model of 
'Financialisation."' Cambridge Journal of Economics 33(3)" 467-493.

Zezza, G. 2004. "Some Simple, Consistent Models of the Monetary Circuit." Working Paper No. 405. Annandale-on-Hudson, NY: Levy Economics Institute of Bard College.

. 2008. "U.S. Growth, the Housing Market, and the Distribution of Income." Journal of Post Keynesian Economics 30(3): 37 -401.

- 2009. "Fiscal Policy and the Economics of Financial Balances." Intervention: European Journal of Economics and Economic Policies 6(2): 289-310.

— 2011. "Income Distribution and Borrowing. Tracking the U.S. Economy with a 'New Cambridge' Model." In E. Brancaccio and G. Fontana (Eds.), The Global Economic Crisis: New Perspectives on the Critique of Economic Theory and Policy. London, UK: Routledge.

— 2012. "Godley and Graziani: Stock-Flow Consistent Monetary Circuits." In D. B. Papadimitriou and G. Zezza (Eds.), Contributions in Stock-Flow Consistent Modeling: Essays in Honor of Wynne Godley. Houndmills, Basingstoke, Hampshire: Palgrave Macmillan.

Zezza, G. and C. H. Dos Santos. 2006. "Distribution and Growth in a Post-Keynesian StockFlow Consistent Model." In N. Salvadori (Ed.), Economic Growth and Distribution: on the Nature and Causes of Wealth of Nations. Cheltenham, UK: Edward Elgar. 


\section{APPENDIX}

\section{Model SIM}

Model SIM is the simplest model presented in Godley and Lavoie (2007c). The transaction-flow matrix is given by Table 1 and the balance sheet by Table 2 . The economy is closed and composed of three sectors: households who receive wages $W$ in exchange for labor, pay taxes $T$, and consume $C$ out their disposable income $Y D$; firms who produce an output $Y$, which is sold to households and the government, and pay wages in exchange for labor; and a government that buys output $G$ from the firms and receives taxes from the household sector. There is only one asset: money stock $H$. All income that is not consumed by households is thus saved as cash. If households have positive savings, then the government has to have a deficit. The following equations describe the model. ${ }^{32}$ Equation (10) is the hidden equation.

$$
\begin{aligned}
Y D & =W \cdot N-T \\
T & =\theta \cdot W \cdot N \\
C & =\alpha_{1} \cdot Y D+\alpha_{2} \cdot H_{h,-1} \\
Y & =C+G \\
N & =\frac{Y}{W} \\
\Delta H_{s} & =G-T \\
\Delta H_{h} & =Y D-C \\
\Delta H_{h} & =\Delta H_{s}
\end{aligned}
$$

Table 1 Transaction-flow matrix of model SIM

\begin{tabular}{l|ccc|c}
\hline & Households & Production & Governement & $\sum$ \\
\hline Consumption & $-C$ & $+C$ & & 0 \\
Govt. expenditures & & $+G$ & $-G$ & 0 \\
Wages & $+W B$ & $-W B$ & & 0 \\
[Output] & & {$[Y]$} & & \\
Taxes & $-T$ & & $+T$ & 0 \\
Change in money stock & $-\Delta H$ & & $+\Delta H$ & 0 \\
\hline$\sum$ & 0 & 0 & 0 & 0 \\
\hline
\end{tabular}

Table 2 Balance sheet of model SIM

\begin{tabular}{l|ccc|c}
\hline & Households & Production & Governement & $\sum$ \\
\hline Money stock & $+H$ & 0 & $-H$ & 0 \\
\hline
\end{tabular}

\footnotetext{
${ }^{32}$ For simplicity, we have dropped all the supply equal demand equations and removed all the subscripts referring to demand and supply.
} 